\title{
Exploration for candidate biological control agents of the submerged aquatic weed Hydrilla verticillata, in Asia and Australia 1996-2013
}

\author{
Matthew Purcell $\cdot$ Nathan Harms $\cdot$ Michael Grodowitz $\cdot$ Jialiang Zhang • \\ Jianqing Ding $\cdot$ Greg Wheeler $\cdot$ Ryan Zonneveld $\cdot$ Roch Desmier de Chenon
}

Received: 23 August 2018/ Accepted: 25 April 2019/Published online: 4 May 2019

(C) The Author(s) 2019

\begin{abstract}
Monoecious and dioecious forms of the submerged aquatic plant hydrilla, Hydrilla verticillata (Linn. f.) Royle (Hydrocharitaceae) are invasive weeds in the US. Surveys for biological control agents of hydrilla throughout its native range have been conducted since the 1970s. Surveys between 1996 and 2013 focused on China, Southeast Asia and Australia, with 425 collections of hydrilla made in seven countries. Most of the herbivores collected were typical of previous surveys and included three main feeding guilds and taxonomic groups: stem-boring Bagous weevils, leaf-mining Ephydridae flies and defoliating Crambidae moths. Preliminary testing of prioritized agents collected from 1996 to 2013 did not reveal candidates for use as biological control agents
\end{abstract}

Handling Editor: S. Raghu

M. Purcell $(\bowtie) \cdot$ R. Zonneveld

USDA ARS, Australian Biological Control Laboratory (ABCL), c/o CSIRO, Ecosciences Precinct, 41 Boggo

Road, Dutton Park, QLD 4102, Australia

e-mail: matthew.purcell@csiro.au

N. Harms

Environmental Laboratory, Aquatic Ecology and Invasive

Species Branch, U.S. Army Engineer Research and

Development Center, 3909 Halls Ferry Rd, Vicksburg,

MS 39180, USA

M. Grodowitz

USDA ARS Biological Control of Pests Research, Unit,

59 Lee Road, Stoneville, MS 38776, USA with those tested being polyphagous. Further surveys are currently in China and South Korea, where hydrilla forms/genotypes exist that match those found in the US.

Keywords Hydrilla $\cdot$ Hydrocharitaceae .

Alismatales $\cdot$ Herbivorous insects $\cdot$ Native range surveys

\section{Introduction}

Hydrilla verticillata (Linn. f.) Royle (Alismatales: Hydrocharitaceae), or hydrilla, is a submersed aquatic macrophyte that is native to Asia, Australia, Europe, and Africa (Buckingham and Bennett 1998). It was

\footnotetext{
J. Zhang

Invasion Biology and Biocontrol Lab, Wuhan Botanical Institute, Chinese Academy of Sciences,

Wuhan 430074, Hubei, China

J. Ding

School of Life Science, Henan University, Jinmin District,

Kaifeng 47001, Henan, China

G. Wheeler

USDA-ARS Invasive Plant Research Laboratory, 3225

College Ave, Fort Lauderdale, FL 33314, USA

R. D. de Chenon

Parkville, Australia
} 
introduced into the US in the early 1950 s and has since become highly invasive (Schmitz et al. 1991) where it hinders navigation, impacts water intake and delivery systems, limits recreational uses, outcompetes native vegetation, acts as a breeding ground for mosquitoes, and destroys fish and wildlife habitats. Hydrilla is a federally listed noxious weed in the US (USDA APHIS Federal Noxious Weed List; https://www. aphis.usda.gov/plant_health/plant_pest_info/weeds/ downloads/weedlist.pdf), is widely distributed across the US (EDDMapS 2019), and is considered to be one of the world's worst weeds (CABI 2015), damaging aquatic ecosystems. Two hydrilla forms are currently recognized in the US in terms of their reproductive structure/behavior: the dioecious form (male and female flowers located on separate plants; only female plants present in the US) is generally found in the southeastern and south central US, whereas the monoecious form (both male and female flowers found on the same plant) mostly occurs in the central Atlantic and northeastern US (Madeira et al. 2000). Though the dioecious form has been present in the US for nearly 50 years, monoecious hydrilla is widely recognized as a later introduction; it was first identified in the northeastern US in 1982 (Steward et al. 1984) and has since been reported in Alabama, California, Connecticut, Georgia, Indiana, Kansas, Maine, Maryland, Massachusetts, New York, North Carolina, Ohio, Pennsylvania, Washington and Wisconsin (Madeira et al. 2000; True-Meadows et al. 2016).

In the US hydrilla is typically managed through the use of chemical herbicides, though mechanical and biological controls are also used. Continuous use of a single herbicide has led to the development of herbicide resistance in some Florida lakes (Michel et al. 2004). Mechanical control is expensive and ineffective for the long-term control of this weed. Management tools are needed for areas where chemical and/or mechanical methods are not effective or economical. The introduction of the herbivorous fish, Ctenopharyngodon idella (Cypriniformes: Cyprinidae) (grass carp), can suppress hydrilla effectively but unfortunately it also feeds on a wide variety of native plant species (Hanlon et al. 2000). In 1992, a native midge, Cricotopus lebetis Sublette (Diptera: Chironomidae), was discovered attacking the apical meristems of hydrilla in Florida (Cuda et al. 2002). The larvae kill the apical meristems changing the architecture of hydrilla, impacting surface mat formation (Cuda et al.
2011). The midge occurs naturally in Florida ecosystems (Stratman et al. 2013a, b). C. lebetis is being mass reared and released as part of an integrated approach for hydrilla control, but widespread impacts have not been recorded (Cuda et al. 2016).

Hydrilla has been surveyed for potential biological control agents in various parts of its native range since the late 1960s (Balciunas et al. 2002) with surveys conducted in Africa, Asia and Australia. These surveys were undertaken to compile lists of the natural enemies of hydrilla throughout its native range. Foreign scientists were contracted to conduct most surveys in conjunction with overseas trips by US scientists. Surveys of Northern and Eastern Australia (1984-1992), China (1989 and early 1990s), eastern Africa (1976, 1981-1984), India (late 1960s, 1982) and Pakistan (1971-1976) were extensive, though trips to Panama (late 1970s, 1980), the Philippines (1982) and Southeast Asia, including Indonesia (1982), Malaysia (early 1970s and 1982), Thailand (1982 and 1996) and Vietnam (1996), involved only brief surveys. Many phytophagous insects were found from these regions though few were selected as potential agents due to their lack of specificity, availability and limited impact to hydrilla. The herbivores discovered in these surveys are summarized by Balciunas et al. (2002).

Two promising insects were both approved for release in the US, the tuber-feeding weevil from Pakistan, Bagous affinis Hustache (Coleoptera: Curculionidae), and a leaf-mining fly from India/Pakistan, Hydrellia pakistanae Deonier (Diptera: Ephydridae) (Buckingham 1988). B. affinis was initially released at Lake Tohopekaliga, Osceola County, Florida in April 1987 (Buckingham 1988). Adults feed on submerged and stranded hydrilla stems during periods of high water, and females oviposit in hydrilla stems, moist wood and soil during drawdowns. Neonate larvae emerge and then enter the soil in search of hydrilla tubers in which they feed and pupate. Unfortunately, this insect failed to establish following mass rearing and multiple releases in three states (Balciunas et al. 2002; Godfrey et al. 1994; Grodowitz et al. 1995). In its native range, extended dry periods and waterbody drawdowns are required for this weevil to complete its life cycle on shore. These conditions are uncommon in the US and this is thought to be the reason for its lack of establishment (http://entnemdept.ufl.edu/creatures/ BENEFICIAL/Bagous_affinis.htm). Hydrellia pakistanae 
was released at Lake Patrick, Polk County, Florida, in October 1987 (Buckingham 1988). Females lay eggs on emergent leaves and stems of hydrilla as well on other aquatic plants growing in close proximity to hydrilla and larvae mine the leaves. H. pakistanae has also been released in Alabama, southern Florida, Georgia, Louisiana and Texas, though establishment has not occurred in Louisiana (Center et al. 1997). This leaf-mining fly is widespread and damaging but its impact on hydrilla in the field is limited (Doyle et al. 2002; 2007; Grodowitz et al. 2003; Owens et al. 2006, 2008) due to abiotic and biotic factors (Wheeler and Center 2001; Cuda et al. 2008) such as parasitism (Coon et al. 2014).

Two insects found in Australia were also released in the US: a stem-boring weevil Bagous hydrillae O' Brien (in 1991) and another leaf-mining fly Hydrellia balciunasi Boch (in 1989). Though the weevil was thought not to have established, one adult was recovered during 2009 in southern Louisiana, some 13 years after releases were terminated at the closest release site, and more than $580 \mathrm{~km}$ away. However, there is no evidence of impact on hydrilla (Center et al. 2013). Although H. balciunasi has a similar biology to $H$. pakistanae, it was consistently replaced by $H$. pakistanae at release sites (Center 1992). In periodic collections following release of these flies, the percentage of $H$. balciunasi would decrease until it could not be recovered from samples. It persists in very low numbers at several sites in Texas (Grodowitz et al. 1997; Cofrancesco et al. 2005).

The moth Parapoynx diminutalis Snellen (Lepidoptera: Crambidae) which is native to tropical Asia, was discovered in Florida in the mid-1970s (Delfosse et al. 1976), probably accidentally introduced into the US. It has spread throughout Florida and damages hydrilla at some sites (Balciunas and Habeck 1981) but cooler temperatures reduce populations to almost undetectable levels (Buckingham and Bennett 1996). This moth is very common in its native range and causes extensive damage to hydrilla including complete defoliation.

Following the release and establishment of biological control agents in combination with other forms of control, hydrilla has remained a large scale intractable and expanding problem across the US. Hydrellia pakistanae, $H$. balciunasi, $P$. diminutalis and $C$. lebetis are insufficient for the control of hydrilla. Biological control could provide further options for controlling hydrilla with new agents that are better adapted to the introduced hydrilla forms in the US and can thrive in the ecosystems where hydrilla is problematic (canals, rivers and lakes which rarely have large fluctuations in water levels). To that end, foreign surveys for new agents were conducted in the center of diversity of hydrilla in China and in unsurveyed areas of Asia and Australia between 1996 and 2013 and are reported here. Periodic reports of surveys in China were produced as online technical notes by the US Army Corps of Engineers, Engineer Research and Development (USACE ERDC) Library (Ding et al. 2011; Harms et al. 2017; Zhang et al. 2012) and in an unpublished report by the Florida Department of Environmental Protection (Ding et al. 2011). The results from these reports are combined in this paper to provide a complete review of Asian and Australian exploration for biocontrol agents of hydrilla between 1996 and 2013.

Hydrilla surveys were conducted by staff of the United States Department of Agriculture Agricultural Research Service (USDA ARS), Australian Biological Control Laboratory (ABCL) in Brisbane, Australia and the USDA ARS Invasive Plant Research Laboratory (IPRL) in Fort Lauderdale, Florida in collaboration with the USACE ERDC, Chinese Academy of Sciences (CAS), Royal Irrigation Department of Thailand, French Center for International Research and Development (CIRAD), Thailand Department of Agriculture, USDA ARS, Sino-American Biological Control Laboratory (SinoABCL), National Biological Control Research Center (NBCRC) Thailand and Vietnamese National Biological Control Research Center (VNBCRC). Surveys were also conducted by researchers from the University of Florida in Africa, but the results of these surveys are not reported here. Surveys focusing on determining herbivores associated with monoecious and dioecious hydrilla forms have been conducted since 2013 and are ongoing.

\section{Materials and methods}

Locations and collections

Surveys for biological control agents of hydrilla were conducted between 1996 and 2013 as part of defined 
exploration projects for hydrilla or opportunistically while conducting surveys for biological control agents for other target weeds. Specific projects were conducted for the Florida Fish and Wildlife Conservation Commission between 2004 and 2009 in Australia, China, Indonesia, Malaysia, Singapore and Thailand and for the US Army Engineer Research and Development Center, Vicksburg, MS between 2011 and 2013, primarily in China but also in Australia and Singapore. A single four-week collaborative survey of Thailand and Vietnam was conducted in 1996 by the ABCL, IPRL and Sino-ABCL.

Site types included natural wetlands, ponds, lakes and rivers as well as man-made canals, irrigation ditches and urban ornamental ponds. At each site, plants were collected from the shore, by wading, or from a boat by hand collecting or by throwing a metal rake with a rope handle to snag plant material. Plants were briefly examined for damage which was recorded and herbivores were collected and preserved. Hydrellia flies were usually found on hydrilla topping out at the water surface or collected by placing a plastic sheet on the water surface, to which they were attracted. Field collected hydrilla was then placed (approx. $1 \mathrm{~kg}$ per site if available) into a plastic bag for transportation back to the place of processing, usually the laboratory or a hotel room when travelling remotely.

Intensive surveys for biological control agents of hydrilla were conducted along the east coast of Australia and the Northern Territory between 1985 and 1992 (Balciunas et al. 1996). However, the remote northern areas of Western Australia, where hydrilla was known to occur, were not surveyed and therefore included in our surveys from 2005 to 2009 . Herbarium records exist for hydrilla in the north of Western Australia, concentrated around Kununurra in the northeast and along the Fitzroy River in north central areas. These regions are remote (especially the Fitzroy River) and surveying is difficult. During the monsoon, surveys had to be carefully planned to avoid periods of flooding when hydrilla could be flushed from aquatic systems or access to sites was restricted. In periods of drought, permanent water sources could be too remote to be accessible.

Between 2006 and 2013, surveys were conducted across 12 provinces of China from Yunnan in the southwest through to Heilongjiang in the northeast. Surveys were conducted from Spring through Autumn before hydrilla died back during the winter months.
Surveys were conducted in North Sumatra between 2001 and 2007 by ABCL and CIRAD staff, as well as local contacts. Most surveys were carried out near Marihat, Pematang Siantar though limited collections were also made at Lake Toba.

In Malaysia a single site was surveyed at Putra Juya, south of Kuala Lumpur in peninsular Malaysia in 2001. A second more extensive survey was conducted in peninsular Malaysia during April 2004. A limited number of hydrilla sites could be found; larger lakes and water impoundments were devoid of any aquatic plant species. This could be attributed to seasonal fluctuations in water levels (likely) or the stocking of herbivorous fish such as grass carp. Only four sites were located where collections could be performed. One site was in an old mine on the central east coast near Kuantan (Pahang), a second site was an irrigation canal north of Penang in the northwest province of Kedah, a third was in an irrigation canal in Perak Province, north of Kuala Lumpur, while the final site was also an irrigation canal north west of Johor Bahru in the south of the country. A brief survey was conducted in Sabah and Sarawak in 2009: 15 sites were surveyed which included irrigation channels, roadside drainage, rice paddys and ponds.

Surveys of hydrilla were made in Singapore from 2001 to 2011. No natural sites were located with collections being made in drainage canals, water storage reservoirs or in the Singapore Botanic Garden.

Extensive areas of Thailand were surveyed between 1999 and 2007. Much of the country was explored and we are confident that most of the potential herbivores were collected in hydrilla samples taken from across the country. Hydrilla was common in the large natural lakes and man-made water impoundments particularly east and northeast of Bangkok. Therefore, most effort was directed to this region. A smaller number of collections were also made in irrigation channels, natural wetlands and ponds in public parks.

In 1996, a four-week survey was conducted in Vietnam. Extensive flooding prior to and during the survey had a significant impact on hydrilla and its associated herbivores. Much of the hydrilla had been flushed out of the water systems, especially at natural sites, while in other areas the hydrilla was completely submerged rendering it inaccessible to many insects. Most of the hydrilla sites visited during the survey were man-made, mainly rice paddies. Hydrilla is constantly removed from these paddies by farmers for 
general maintenance, which precluded the establishment of a significant population of herbivores. Natural sites, or sites where hydrilla was permanently established, were difficult to find.

\section{Processing Hydrilla Samples}

Hydrilla brought back from the field was processed in one of three ways:

1. Hand searching: Hydrilla was carefully searched using a hand lens, magnified binocular glasses or under a magnified lamp. This technique was useful for detecting damage caused by insect larvae that fed internally within stems and leaves. Pupal cases and insects feeding externally on hydrilla were easily found and collected. Plant samples could be processed in a short time by hand searching.

2. Berlese funnels: Small Berlese extraction funnels (50 cm high, $25 \mathrm{~cm}$ diam.) were used when 2-3 days were available for processing at a given location. Hydrilla placed in the funnels was slowly dried by the heat produced by light bulbs, forcing insects into a collection cup, which was checked daily. Light bulbs of several wattages were used to dry hydrilla of varying quantities, and to increase/ decrease the drying period. This technique was particularly successful for collecting Hydrellia (Diptera: Ephydridae) immatures and adults, as well as Acentropinae (Lepidoptera: Crambidae) and midge (Diptera: Chironomidae) larvae and this method proved to be more efficient for collecting herbivores than hand searching. Unlike hand searches, this technique could not determine the field habits of herbivore species, and their associated feeding damage, which would have to be examined post-extraction. Placement of herbivores extracted from the funnels onto fresh plant material was used to determine habit after collection.

3. Pan-drying: Hydrilla was placed on wire mesh above large (60 cm diam.) pans containing water. As the material dried under ambient conditions, the insects were forced into the pan below. Unfortunately, mobile adults such as moths or flies were rarely collected as they could easily escape. This technique had similar benefits to Berlese funnels, but was especially useful for processing large amounts of hydrilla, or while traveling (dried in vehicle). Many Bagous weevils, Hydrellia larvae and Acentropinae larvae were collected from pan-dried hydrilla.

Generally, immature insects collected by all three processes were reared to the adult stage in plastic cups or preserved, though various rearing techniques were employed dependent upon insect habit. Field collected adults, or adults reared from immatures, were preserved or placed in oviposition cages or chambers.

Testing potential biological control agents

The host range of Bagous species from Asia was conducted in quarantine by ABCL staff in Australia or by CAS staff in the laboratory in Wuhan, China. Both no-choice and choice testing was employed using cut hydrilla and test plant material within sealed plastic food containers of various sizes. Adults were placed on the material then removed after three to four days and immatures were reared to adult. A test was also conducted on Bagous from Thailand to determine if it was capable of underwater development. Adults were placed onto submerged hydrilla for $24 \mathrm{~h}$ in four containers and the hydrilla was removed (1) immediately, (2) after one week, (3) after one month and (4) after two months and placed onto moist paper toweling to monitor development of immatures to the adult stage.

In no-choice host range testing of Crambidae moths, neonate larvae were transferred from oviposition substrate (moist toweling) directly onto test plants. Development and survival of immatures was subsequently recorded.

\section{Results}

Table 1 lists the country and number of collections conducted between 1996 and 2013 for exploration of biological control agents of hydrilla. Table 2 lists the herbivores of interest that were collected.

\section{Australia}

Hydrilla collections were made from an irrigation channel (S1547.926 E128 $\left.{ }^{\circ} 41.394,2006 / 2007 / 2009\right)$ and a natural lake at Kununurra (S15 46.840 E128 44.492, 2005/2007), near the border with the Northern Territory. The most common herbivore from 
Table 1 Collections conducted in Australia and Asia for biological control agents of Hydrilla verticillata between 1996 and 2013

\begin{tabular}{llcc}
\hline Years & Country & Provinces/States & Collections \\
\hline 2002-2013 & Australia & 3 & 31 \\
$2006-2013$ & China & 12 & 87 \\
$2001-2007$ & Indonesia & 1 & 33 \\
$2001-2009$ & Malaysia & 6 & 19 \\
$2001-2013$ & Singapore & 1 & 40 \\
$1999-2007$ & Thailand & 29 & 194 \\
1996 & Vietnam & 12 & 19 \\
Total collections & & 423
\end{tabular}

these sites was $H$. balciunasi, the fly already released in the US Mites were also collected from these samples, but they failed to feed on hydrilla in laboratory trials. A collection was also made at Lake Argyle (S16 $\left.07.160 \mathrm{E} 128^{\circ} 44.492\right)$ in 2005: a single Bagous weevil larva was extracted from the material but the specimen died in rearing and was preserved. Subsequent attempts to re-collect this weevil from this (2006/2009) and a nearby site (Deadhorse Spring; S16 05.324 E128 $45.595,2007 / 2009)$ failed: only $H$. balciunasi was reared.

In 2007 and 2009 hydrilla samples were also collected from Marlgu Billabong (S15³2.938 E128 ${ }^{\circ} 15.568$ ), a permanent natural lake near Wyndham on the Western Australian north coast. This natural site was of interest given that the system could not be flushed and hydrilla grew undisturbed amongst many other aquatic plant species. Once again, $H$. balciunasi and aquatic mites were extracted from the samples. Two Donaciinae (Coleoptera: Chrysomelidae) larvae were also collected feeding on roots and stems of hydrilla but could not be kept alive while surveying due to a requirement for live plant material. Although adults were not reared they are likely to be Donacia australasiae Blackburn, the only known Australian representative in the genus (Reid 1993). It was collected in Australian hydrilla surveys conducted between 1985 and 1992. They are non-specific and cause minimal damage to plant tissue. A large Bagous weevil, whose adults actively swim under water to access submerged stems and leaves of hydrilla, was also collected from the billabong. In the laboratory, females laid eggs under water in hydrilla stems but the eggs failed to hatch. This species was identified by a taxonomist at the Australian National Insect Collection (ANIC) as Bagous natator O'Brien, previously collected as adults from hydrilla, Ceratophyllum demersum L. (Ceratophyllaceae) and Vallisneria gracilis F.M. Bailey (Hydrocharitaceae) in the 1985-1992 Australian surveys.

Surveys of the Fitzroy River in 2005, 2006 and 2007 failed to find hydrilla. The river was searched near the township of Fitzroy Crossing (S18 ${ }^{\circ} 11.579$ E125 34.877$)$ and at Geikie Gorge (S18 05.543 $\mathrm{E} 125^{\circ} 42.585$ ), further upstream and north of the township, but no aquatic plant species were located. Discussion with the traditional owners of the region revealed that aquarium-type plants were located in some remote ponds within the Geikie Gorge National Park, which may be surveyed in future.

All river systems along the Gibb River Road, which runs from east to west across the Kimberley region, were searched but hydrilla could not be found. These surveys covered approximately $1300 \mathrm{~km}$ of fourwheel drive only access roads from Kununurra on the eastern border, west to the Fitzroy River Region, and north to the Mitchell Plateau on the remote northern coast. Many other aquatic plant species were observed in the permanent water bodies. Sites were visited where herbarium records existed for hydrilla in the town of Broome (S17 $\left.57.686 \mathrm{E} 122^{\circ} 14.151\right)$ on the west coast, but these water bodies were dry when visited.

China

Four Bagous weevil species were discovered in China whose larvae mine the stems of hydrilla. Specimens were identified by Dr Charles O'Brien, a retired specialist in weevil taxonomy based in Arizona, USA. In Hunan Province, B. chinensis Zumpt was collected from hydrilla growing in the flowing water of the Liaojiachong River (N28 12.253 E109³8.956). This is a distinctly different habitat from Bagous collection sites in Australia and Thailand which were lakes, dams and reservoirs. Despite this, larvae would only pupate out of water on stranded hydrilla or paper towelling even though it was not apparent that equivalent conditions existed at the field site for pupation to occur. Host range testing in China revealed that this weevil could develop on four other aquatic Hydrocharitaceae species: Elodea nattallii 


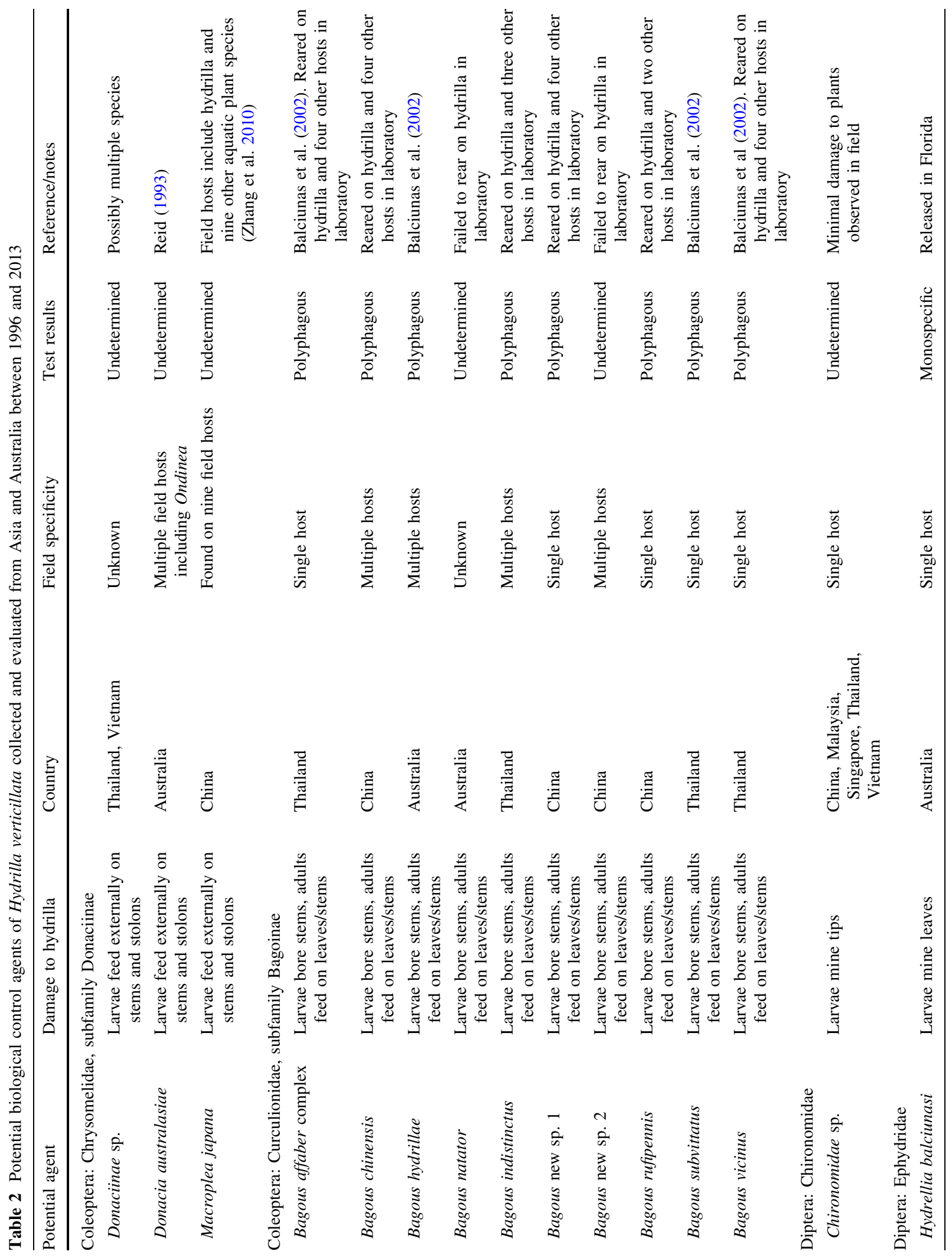




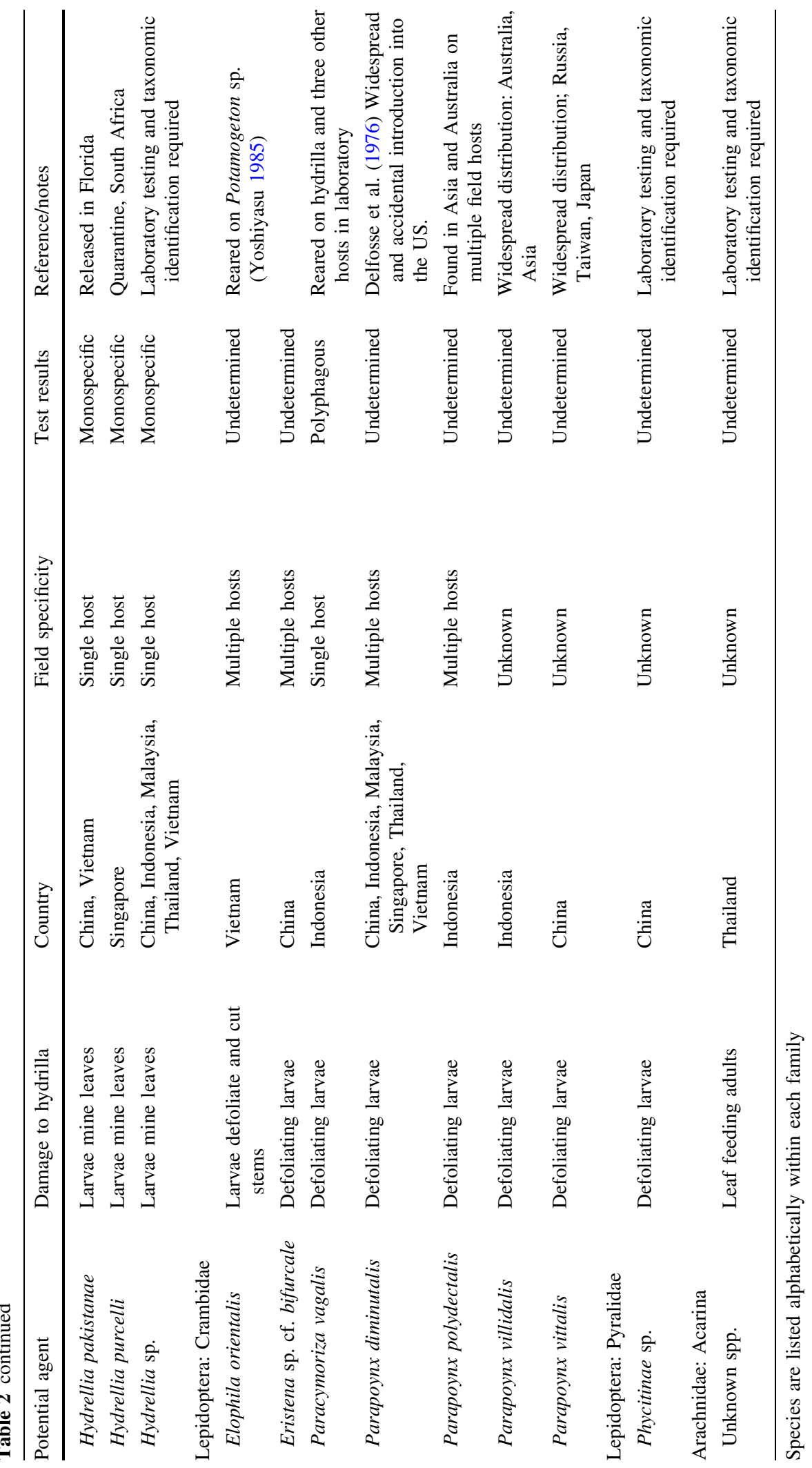


(Planchon), Egeria densa (Planch.) Casp., Vallisneria natans (lour.) Hara, and Hydrocharis morsus-ranae L. (Ding et al. 2009).

Bagous rufipennis Egorov \& Grachev was imported into quarantine in Australia from a small number of adults collected from Lijiafan Village (N31 ${ }^{\circ} 26.399$ E113 ${ }^{\circ} 34.381$ ) in Hubei Province. No-choice host range testing was initiated in 2012. Bagous rufipennis was reared on hydrilla as well as $V$. spiralis L. (Hydrocharitaceae) and E. densa. Choice tests were conducted in China where the weevils fed substantially on Najas marina L. (Hydrocharitaceae), E. nuttallii and Largarosiphon alternifolia (Roxb.) (Hydrocharitaceae) with minimal feeding also observed on V. natans, Myriophyllum verticillatum L. (Haloragaceae), Ottelia acuminate (Gagnep.) Dandy (Hydrocharitaceae), Marsilea quadrifolia L. (Marsileaceae), Brasenia schreberi J. F. Gmel (Cabombaceae) and Hydrocharis dubia (Blume) Backer (Hydrocharitaceae). Five adults developed on E. nuttallii and one on L. alternifolia. These results indicated that $B$. rufipennis was not specific to hydrilla.

In 2008, an undescribed weevil, Bagous sp. 1, was collected from the fast-flowing Li River in Guangxi Province. Larvae were reared from hydrilla stranded on the shoreline and host range testing found that this species could develop on four other aquatic plant species: L. alternifolia, E. nattallii, N. marina, and N. minor All.

A second undescribed species, Bagous sp. 2, was first collected at a site near Hemufan Village (N31 46.645 E113 $\left.{ }^{\circ} 07.444\right)$ in Suizhou City, Hubei Province, in 2010 (Ding et al. 2011). This weevil was of great interest given that, in the laboratory, larvae pupated along the stem in cocoons covered by algae. These observations indicated that this weevil may pupate underwater. Previously, all other Bagous found on hydrilla have pupated on shore, either in desiccating hydrilla or in tubers. Although as many as 48 larvae of Bagous sp. 2 were obtained from one field collection, it was difficult to collect large numbers of adults in the field, the survival rate of immatures was low and the few reared adults did not oviposit in the laboratory in China. A colony could therefore not be established. Subsequently, adults were imported into ABCL quarantine in Australia in November 2012. As in China, the weevils failed to oviposit on hydrilla and a colony could not be established. The field hosts of Bagous sp. 2 include hydrilla and H. dubia. However, the identity of the adults collected from $\mathrm{H}$. dubia was not verified before use in laboratory tests. It is possible they could have been a similar species, Bagous picturatus Egorov \& Gratshev, also collected from H. dubia nearby in a separate collection at Hemufan Village, and not Bagous sp. 2. Visually B. picturatus is very similar to Bagous sp. 2, but can be distinguished by its inflated tarsal segments, possibly as an adaption to walking on large surface leaves of aquatic plants. Weevils in future collections will be sorted taxonomically before evaluation.

Aquatic moth larvae were collected from sites across all surveyed regions of China. Most specimens were identified as the generalist $P$. diminutalis, which is already present in the US. Other species reared include an undescribed Phycitinae (Lepidoptera: Pyralidae) species, $P$. vittalis Bremer (Lepidoptera: Crambidae), and Eristena sp. cf. bifurcale Pryer (Lepidoptera: Crambidae), a species not specific to hydrilla, which also feeds on Potamogeton (Potamogetonaceae), Blyxa (Hydrocharitaceae) and aquatic lichens.

Larvae and adults of a leaf-mining fly Hydrellia sp. were collected from most sites. Though the adults were not formally identified, previous specimens collected in China were identified as $H$. sarahae sarahae Deonier, a species also collected from India and whose host range appears broad (Balciunas et al. 2002), or H. pakistanae.

In 2006, larvae of the Donaciinae beetle Macroplea japana (Jacoby) (Coleoptera: Chrysomelidae) were collected feeding underwater on hydrilla roots. Buckingham (1998) collected Donaciinae larvae in China but these specimens were not reared, though they were likely $M$. japana. The species was found in five provinces: Guangxi, Guizhou, Hubei and Hunan (Zhang et al. 2010) in southern and central China as well as in the northern province of Heilongjiang. It is a generalist species whose host plants in our surveys included hydrilla, Nymphoides peltatum (Gmel.) (Menyanthaceae), V. spiralis, Potamogeton malaianus Linn. (Potomogetonaceae), Potamogeton maackianus A. Bennett (Potomogetonaceae), O. acuminata, M. verticillatum and Alopecurus aequalis Sobol. (Poaceae) (Zhang et al. 2010). However, even when at high population densities such as at the Huaxi and Wen Cheng Rivers in Guizhou Province, there appears to be little effect on hydrilla growth. 
Chironomidae larvae were very common on hydrilla at almost all sites in China. These midges usually attack the apical tips of hydrilla where damage has minimal impact. Damage at some sites consisted of burrows or retreats formed in stems between internodes, within $10 \mathrm{~cm}$ of the growing tip.

\section{Indonesia}

The most damaging insects in Sumatra were defoliating crambid moths. The larvae of one species completely defoliated hydrilla growing along the streams flowing through oil palm plantations throughout the year, removing all foliage from the mats. They have been tentatively identified as Paracymoriza vagalis (Walker) (Lepidoptera: Crambidae). Adults were sent to Dr. Shen-Horn Yen, an aquatic moth specialist based at National Sun Yat-sen University in Taiwan. The entire genus (Paracymoriza) is not a natural taxonomic group as it comprises several species assemblages that are not related to each other. There are eight described species in this genus from the Asian region, six of which are from Southeast Asia. In the literature, $P$. vagalis was thought to be a specialist on Podostemaceae when its larvae were first discovered in Japan, but apparently the true P. vagalis in Taiwan and Japan would defoliate Potamogeton and other submersed aquatic plants. The true Paracymoriza (species related to $P$. vagalis) include $P$. laminalis Hampson and $P$. aurantialis Swinhoe and an unidentified species. ABCL specimens from Sumatra have mixed characters of both $P$. vagalis and $P$. aurantialis. A formal description is required.

Thousands of larvae have been collected and observed on hydrilla at Manning Kring (N02 ${ }^{\circ} 54.653$ E99 05.992) near Pematang Siantar in central North Sumatra. However, these water courses are often flushed due to heavy rain and most of the hydrilla and moths temporarily disappear. Both the plant and the moth populations recover quickly in a boom/bust cycle of development. As they develop, the larvae become quite large, up to $2-3 \mathrm{~cm}$ in length, and are very damaging. They form cases amongst the hydrilla constructed primarily of hydrilla leaf and stem fragments as well as sedimentary and moss/algal components. The cases appear to be used for protection though larvae frequently vacate these shelters to feed on surrounding material. Most larvae are found where the stream flow is strongest, seemingly preferring the heavily oxygenated water. By removing the hydrilla from the flow, large numbers of larvae can simply be removed by hand from the plant material given that they are very active. Pupation occurs within sealed cases which could also easily be collected.

Larvae were imported to Australian quarantine on several occasions. Initially, host testing of this moth was impossible as we were unable to induce $P$. vagalis to oviposit under laboratory conditions. After trialing many laboratory techniques, a system was developed whereby mated females were exposed to draped wet toweling sheets on which they lay thousands of fertile eggs. No-choice host range testing indicated that this moth could complete its life cycle on hydrilla and three other plant species: C. demersum, E. densa and $V$. gracilis. These results were not promising given that $C$. demersum is not even in the same family as hydrilla, indicating a broad host range. Additionally, $V$. americana is a valued native aquatic plant in the US and given these results it could be an alternate host of this moth were it to be released in the US. However, given its significant impact on hydrilla, evaluation of its field host range in Sumatra could be warranted.

Three other species of defoliating Crambidae moths were collected in Sumatra, but Parapoynx diminutalis, $P$. polydectalis Walker and $P$. villidalis Walker (= Nymphula villidalis) are not as damaging to hydrilla. Parapoynx polydectalis has a widespread distribution in Australia and is not specific to hydrilla given specimen records at the ANIC. ANIC specimens of $P$. villidalis collected from Queensland and New South Wales in Australia have unknown field hosts.

\section{Malaysia}

In peninsular Malaysia insects collected from hydrilla at three sites in 2001 and 2004 included the generalist defoliating moth, $P$. diminutalis, Hydrellia sp. flies and Chironomids. Surveys at 15 sites in Sabah and Sarawak in 2009 detected the same herbivores.

\section{Singapore}

A leaf-mining Hydrellia fly was collected regularly from all Singapore sites. Specimens were sent to the Agricultural Research Council - Plant Protection Research Institute (ARC-PPRI) in South Africa where these flies underwent host range testing for use against an exotic hydrilla genotype that was introduced into 
that country. There was also a native genotype. Sequencing of the hydrilla from exotic infestations of hydrilla in South Africa indicated that the plant's introduction probably originated from the Malaysian region (Madeira et al. 2007). The unknown fly was subsequently described as Hydrellia purcelli Deeming (Bownes and Deeming 2016) and appears to be adapted to the South African exotic hydrilla genotype (Bownes 2016). Madeira et al. (2007) thought it prudent to introduce control agents into South Africa from Southeast Asia or Indonesia.

The generalist moth $P$. diminutalis was also collected from Singapore sites. Additionally, Chironomidae damaging apical tips were collected from Sungei Buloh between 2001 and 2004 and preserved.

\section{Thailand}

Four species of Bagous weevils, whose larvae mine the stems of hydrilla, were collected in Thailand. At least three of these species had been collected previously: Bagous subvittatus O'Brien \& Morimoto from Thailand, $B$. affaber Faust from India and B. vicinus Hustache from Pakistan (Balciunas et al. 2002). An undescribed polyphagous species of Bagous was previously collected from Thailand but it is unknown whether this was the same as that collected in our surveys as specimens were not available for comparison. Our species was subsequently identified as $B$. indistinctus O'Brien.

Larvae of all Bagous species were found in the stems of submerged plants indicating these species are at least partly aquatic. Bagous vicinus had been collected in previous surveys but it was uncertain whether larvae only fed on desiccating hydrilla stems (Balciunas et al. 2002). Bagous subvittatus was only collected on one occasion and was not recovered in further surveys. Laboratory studies have already indicated that this species is not specific (Bennett and Buckingham 2000). The three remaining species, $B$. affaber, B. indistinctus and B. vicinus, were imported into ABCL quarantine in Australia to evaluate their specificity and impact. In host range testing, all three species were found to be non-specific. All three species completed development on hydrilla as well as E. densa, P. perfoliatus and V. gracilis. Bagous affaber and B. vicinus also developed on $P$. crispus.
Bagous affaber collected from completely sub-

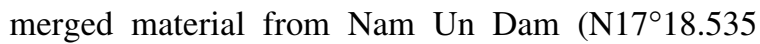
E103 $\left.{ }^{\circ} 44.618\right)$ and Prapong Dam (N13 59.267 $\left.\mathrm{E} 102^{\circ} 26.818\right)$, where there were no apparent shoreline sites for pupation, preferred to oviposit on submerged plants while those collected from stranded material preferred this material for oviposition indicating that cryptic species may exist. The specimens were indistinguishable using external morphological characters.

The results of the underwater development test of $B$. indistinctus indicated that once eggs are laid underwater they did not develop until the plant material became stranded (transferred to paper). Even when the hydrilla remained submerged for two months after oviposition, then removed and placed on paper toweling, the development time after removal was similar to immatures on hydrilla removed from water and placed onto toweling immediately following adult oviposition. This indicates that this weevil species is adapted to water level drawdowns in Thailand. However, this was confounded by field observations where larvae have been extracted from submerged hydrilla at field sites. Underwater development remains unresolved and these tests need to be completed for the other Thailand Bagous species. We did verify that $B$. vicinus was collected from both stranded hydrilla material and from hydrilla growing near shore. However, in the quarantine laboratory, this species preferred to oviposit out of water on hydrilla/paper toweling while $B$. affaber complex specimens mostly (sometimes exclusively) oviposit underwater. Despite these findings, larvae of all tested species would only pupate out of water on stranded hydrilla/paper toweling.

An undescribed Hydrellia sp. was also collected from most sites in Thailand. In previous surveys by the IPRL scientists, this species was shipped to quarantine in Florida in 1997 but testing was incomplete. Parapoynx diminutalis was also collected from many sites across Thailand. No other aquatic moth species were collected. Donaciinae larvae were uncommon and collected from Lam Pao Dam (N16³6.479 $\mathrm{E} 103^{\circ} 26.227$ ) in the northeast (Kalasin) and from the Thale Noi wetland (N07 46.665 E100 07.404$)$ in the southern province of Phatthalung. Like Donaciinae, collected elsewhere, these larvae had little or no apparent impact when feeding externally on hydrilla stems. It is possible that it is the same species found in 
China, M. japana. Mites collected from Lam Pao Pond $\left(\mathrm{N} 16^{\circ} 36.675 \mathrm{E}^{2} 3^{\circ} 25.989\right)$ and Nam Un Dam actively fed on the leaf margins of hydrilla. These specimens are yet to be identified and little is known about their specificity and impact on the plants. Due to permitting restrictions, we are unable to import mites into ABCL quarantine in Australia for further evaluations. A second, larger mite species was extracted from a sample collected at Tha-Rae (N17 ${ }^{\circ} 15.368$ E104 ${ }^{\circ}$ 99.628) on Nong Harn Lake (Sakhon Nakhon) but this species did not feed on hydrilla. Chironomidae fly larvae were collected from Lam Nang Rong and Huay Jonakae Maq Reservoir (Buriram), Lam Pao Pond (Kalasin) and Nam-Un Dam (Sakhon Nakhon). Larval specimens hand-carried to Australia failed to emerge as adults in quarantine.

\section{Vietnam}

The most common species collected from hydrilla in Vietnam were $H$. pakistanae flies whose larvae mine the leaves of hydrilla. These flies were found at seven of the 17 sites where hydrilla was collected, although densities were very low. Adults were collected directly from the field and larvae collected during hand searches or from hydrilla processed in Berlese extraction funnels or by sun drying. Pupae were collected only in hand searches.

Field specimens of $H$. pakistanae and those reared were then shipped to IPRL quarantine in Gainesville, Florida. The $H$. pakistanae specimens were identified in Florida as being very similar to those collected previously in China that had already been released in Florida and were therefore preserved.

Aquatic crambid moth larvae were collected from five sites surveyed in Vietnam. Field populations at collection sites were low, and larval damage was insignificant. There were at least two species present. Like Hydrellia, they were reared in plastic containers with water and hydrilla and emerging adults were preserved.

Parapoynx diminutalis larvae were collected from four sites in Vietnam while unidentified case-forming larvae were also extracted from a hydrilla sample collected at Go Dau. Unlike the other acentropine species collected on hydrilla, these larvae have no external gills. They were voracious feeders, consuming leaves and cutting stems. The larvae pupated within the cases and two adults emerged. Both specimens were preserved and identified as Elophila orientalis Speidel (Lepidoptera: Crambidae). This species has been previously collected from Japan and reared on Potamogeton sp. (Yoshiyasu 1985). It was therefore not considered for further testing.

Midge larvae were collected from hydrilla at six sites in Vietnam. These larvae damaged the apical meristems of hydrilla. This damage was recognisable by a small exit hole on the side of the apical bud. The larval feeding often caused the bud to detach from the plant. No attempt was made to rear these larvae, and all specimens were preserved in alcohol. Thirty-nine larvae of Donaciinae sp. were also collected from hydrilla from Buu Long Lake, Bien Hoa district, Dong Nai province, $40 \mathrm{~km}$ north-east of Ho Chi Minh City, and preserved.

\section{Discussion}

Despite extensive surveys throughout Asia and Australia, very few specific herbivores were found to cause damage to hydrilla. As in previous surveys, typically there were three groups which caused significant damage: host-specific Hydrellia spp. flies, whose larvae mine the leaves of hydrilla; polyphagous Bagous weevils, whose larvae mine hydrilla stems; and polyphagous moths, whose larvae defoliate stems.

Insects that could be pursued further are the Hydrellia flies. Although $H$. pakistanae has been introduced into the US as a biological control agent with limited success, other candidate agents from the surveys presented may potentially have a greater impact. Paying particular attention to better matching the hydrilla forms and genotypes between the native range and the US would require further exploration in Korea and China (monoecious/dioecious form) and the Indian subcontinent (dioecious form).

There remain several species of Bagous weevils from China and crambid moths from China, Indonesia and Thailand which need to be evaluated for specificity. There is also the potential that cryptic species are masquerading as a polyphagous taxon. Therefore, representatives of all species from multiple locations should be genetically characterized to analyze the possibility of host-specific cryptic species. Additionally, insects such as the crambid moth, $P$. vagalis, that cause extensive damage to hydrilla in the native range 
but have been found to be not specific in laboratory testing, should have their field host ranges evaluated.

Chironomidae larvae attacking tips of hydrilla should be colonized and their specificity and impact identified. Polypedilum sp. nov. (Diptera: Chironomidae) have been considered as potential biological control agents for Largarsiphon major (Hydrocharitaceae), an invasive close relative of hydrilla in Ireland (Earle et al. 2013). Mites from Thailand should also be assessed since it has been verified that they do feed on hydrilla leaf tissue.

All remaining, poorly surveyed areas within the native range of hydrilla should be explored for hostspecific herbivores and a complete inventory of hydrilla herbivores created. Even if new and specific agents are not discovered, there is value in eliminating all possibilities given that hydrilla remains one of the most serious aquatic weeds in the US and all control options will be revisited when solutions are sought to contain this plant. Areas that should be explored include Bangladesh, Burma, Cambodia, Russia and unsurveyed areas of China, Indonesia, Korea and Vietnam.

Hydrilla forms and genotypes: implications for existing and future surveys

Genetic characterization of hydrilla samples by Madeira et al. (1997, 2004, 2007) identified the likely origin of the dioecious form as the Indian subcontinent, even though reports suggested that introductions occurred from Sri Lanka. The same studies suggested that South Korea is the origin of the monoecious form (Madeira et al. 1997, 2004, 2007). More recent studies by Zhu et al. (2015) identified that the monoecious form exists in both northern China as well as Korea and a match for the dioecious form also occurs in China.

The surveys for biological control agents outlined in this paper were not carried out on monoecious hydrilla in northern China or Korea though previous exploration was conducted, particularly in India in the 1970s (Balciunas et al. 2002) and briefly in Korea (Buckingham 1998). Unfortunately, the forms of hydrilla in the current and earlier surveys were not often recorded. It is likely that host-specific biological control agents for hydrilla collected from matching forms/genotypes in the native range could possibly have greater efficacy given their adaption to these plants. One example could be the lack of success of the leaf-mining $H$. balciunasi collected from the Australian hydrilla genotype and released on the US hydrilla when compared to the more successful related leaf-mining species introduced from India, H. pakistanae, collected from hydrilla matching the US dioecious form. Additionally, evidence from quarantine studies indicate that $H$. purcelli collected from Singapore performs better on the South African genotype of hydrilla that originated from Indonesia/ Malaysia, than does H. pakistanae (Bownes 2016). More recently it has also been suggested that the current introduced agents for hydrilla in the US are less effective on the monoecious plants than on the dioecious plants (Grodowitz et al. 2010).

In view of these results and observations, surveys post-2013 have focused on regions of hydrilla's native range with form/genotype matches for US introductions. South Korea is a high priority for surveying the monoecious form as is mainland China where the monoecious and dioecious forms exist. Recent genetic data indicates that China is the center of diversity for hydrilla (Zhu et al. 2015; Williams et al. 2018), which theoretically could be the source of a more diverse range of natural enemies (Gaskin et al. 2011), warranting further surveys there.

Acknowledgements Dr. Manop Siriworakul (retired, Royal Irrigation Department of Thailand), Dr Thai Van (retired, USDA ARS IPRL), Willey Durden (deceased, USDA ARS IPRL), Tian Baoliang (CAS) and Dr. Chen Ziqhuan (Chinese Academy of Agricultural Sciences) provided invaluable assistance with field collections in Asia. Funding for surveys was provided by the USACE ERDC and the Florida Fish and Wildlife Conservation Commission.

Open Access This article is distributed under the terms of the Creative Commons Attribution 4.0 International License (http:// creativecommons.org/licenses/by/4.0/), which permits unrestricted use, distribution, and reproduction in any medium, provided you give appropriate credit to the original author(s) and the source, provide a link to the Creative Commons license, and indicate if changes were made.

\section{References}

Balciunas JK, Habeck DH (1981) Recent range extension of hydrilla-damaging moth, Parapoynx diminutalis (Lepidoptera: Pyralidae). Fla Entomol 64:195-196

Balciunas JK, Burrows DW, Purcell MF (1996) Australian surveys (1985-1992) for insect biological control agents of 
Hydrilla verticillata. Technical Report A-96-5. US Army Engineers Waterways Experiment Station, Vicksburg

Balciunas JK, Grodowitz MJ, Cofrancesco AF, Shearer JF (2002) Hydrilla. In: van Driesche R, Lyon S., Blossey B, Hoddle M, Reardon R (eds) Biological control of invasive plants in the eastern United States. USDA Forest Service Publication FHTET-2002-04, pp 91-114

Bennett CA, Buckingham GR (2000) The herbivorous insect fauna of a submersed weed, Hydrilla verticillata (Alismatales: Hydrocharitaceae). In: Spencer NR (ed.) Proceedings of the $\mathrm{X}$ international symposium on biological control of weeds, July 4-14, 1999, Bozeman, Montana. Advanced Litho Printing, Great Falls, Montana, USA, pp 307-313

Bownes A (2016) A comparison of host range and performance of congeneric leaf-mining flies, Hydrellia pakistanae (Diptera; Ephydridae) and Hydrellia sp., two candidate biological control agents for the South African biotype Hydrilla verticillata (Hydrocharitaceae). Biol Control 84:44-52

Bownes A, Deeming J (2016) A new species of Hydrellia (Diptera: Ephydridae) mining Hydrilla verticillata (Hydrocharitaceae) leaves in Singapore. Austral Entomol 55:353-359

Buckingham GR (1988) Reunion in Florida-hydrilla, a weevil, and a fly. Aquatics 10:9-25

Buckingham GR (1998) Surveys for insects that feed on Eurasian watermilfoil, Myriophyllum spicatum, and hydrilla, Hydrilla verticillata, in the People's Republic of China, Japan, and Korea. Technical Report A-98-5. US Army Engineer Waterways Experiment Station, Vicksburg

Buckingham GR, Bennett CA (1996) Laboratory biology of an immigrant Asian moth, Parapoynx diminutalis (Lepidoptera: Pyralidae), on Hydrilla verticillata (Hydrocharitaceae). Fla Entomol 79:353-363

Buckingham GR, Bennett CA (1998) Host range studies with Bagous affinis (Coleoptera: Curculionidae), an Indian weevil that feeds on hydrilla tubers. Environ Entomol 27:469-479

CABI (2015) Hydrilla verticillata. In: Invasive species compendium. CAB International, Wallingford. http://www. cabi.org/isc/datasheet/28170. Accessed 26 July 2015

Center TD (1992) Release and field colonization of new biological control agents of Hydrilla verticillata. Miscellaneous paper A-92-2. US Army Engineer Research and Development Center, Vicksburg, pp 205-221

Center TD, Grodowitz MJ, Cofrancesco AF, Jubinsky G, Snoddy E, Freedman JE (1997) Establishment of Hydrellia pakistanae (Diptera: Ephydridae) for the biological control of the submersed aquatic plant Hydrilla verticillata (Hydrocharitaceae) in the southeastern United States. Biol Control 8:65-73

Center TD, Parys KP, Grodowitz M, Wheeler GS, Dray FA, O'Brien CW, Johnson S, Cofrancesco A (2013) Evidence of establishment of Bagous hydrillae (Coleoptera: Curculionidae), a biological control agent of Hydrilla verticillata (Hydrocharitales: Hydrocharitaceae) in North America. Fla Entomol 96:180-186

Cofrancesco A, Grodowitz M, Center T, Balciunas J (2005) Hydrellia balciunasi-Australian hydrilla leaf mining fly. Noxious and nuisance plant management information systems. Engineer Research and Development Center, Vicksburg

Coon BR, Harms NE, Cuda JP, Grodowitz MJ (2014) Laboratory biology and field population dynamics of Trichopria columbiana (Hymenoptera: Diapriidae), an acquired parasitoid of two hydrilla biological control agents. Biocontrol Sci Technol 24:1243-1264

Cuda JP, Coon BR, Dao YM, Center TD (2002) Biology and laboratory rearing of Cricotopus lebetis (Diptera: Chironomidae), a natural enemy of the aquatic weed hydrilla (Hydrocharitaceae). Ann Entomol Soc Am 95:587-596

Cuda JP, Charudattan R, Grodowitz MJ, Newman RM, Shearer JF, Tamayo ML, Villegas B (2008) Recent advances in biological control of submersed aquatic weeds. J Aquat Plant Manag 46:15-32

Cuda JP, Coon BR, Dao YM, Center TD (2011) Effect of an herbivorous stem mining midge on the growth of hydrilla. J Aquat Plant Manag 49:83-89

Cuda JP, Shearer JF, Weeks ENI, Kariuki E, Baniszewski J, Giurcanu M (2016) Compatibility of an insect, a fungus, and a herbicide for integrated pest management of dioecious hydrilla. J Aquat Plant Manage 54:20-25

Delfosse ES, Perkins BD, Steward KK (1976) A new US record for Parapoynx diminutalis (Lepidoptera: Pyralidae), a possible biological control agent for Hydrilla verticillata. Fla Entomol 59:19-20

Ding J, Zhang J, Wheeler G, Purcell M (2009) Exploration of natural enemies in southern China for biological control of hydrilla in Florida, June 2008-May 2009. Unpublished annual report to the Florida Department of Environmental Protection

Ding J, Zhang J, Huang W (2011) Progress report on field surveys to identify biocontrol agents of Hydrilla verticillata in China during 2010. ERDC/TN APCRP-BC-22. US Army Engineer Research and Development Center, Vicksburg

Doyle RD, Grodowitz MJ, Smart RM, Owens CS (2002) Impact of herbivory by Hydrellia pakistanae (Diptera: Ephydridae) on growth and photosynthesis potential of Hydrilla verticillata. Biol Control 24:221-229

Doyle RD, Grodowitz MJ, Smart RM, Owens CS (2007) Separate and interactive effects of competition and herbivory on the growth, expansion, and tuber formation of Hydrilla verticillata. Biol Control 41:327-338

Earle W, Mangan R, O’Brien M, Baars J (2013) Biology of Polypedilum n. sp. (Diptera: Chironomidae) a promising candidate agent for the biological control of the aquatic weed Lagarosiphon major (Hydrocharitaceae) in Ireland. Biocontrol Sci Technol 23:1267-1283

EDDMapS (2019) Early detection and distribution mapping system. The University of Georgia-Center for Invasive Species and Ecosystem Health. Available online at http:// www.eddmaps.org/. Accessed 2 Jan 2019

Gaskin JF, Bon M, Cock MJW, Cristofaro M, De Biase A, De Clerck-Floate R, Ellison CA, Hinz HL, Hufbauer RA, Julien MH, Sforza R (2011) Applying molecular-based approaches to classical biological control of weeds. Biol Control 58:1-21

Godfrey KE, Anderson LW, Perry SD, Dechoretz N (1994) Overwintering and establishment potential of Bagous affinis (Coleoptera: Curculionidae) on Hydrilla verticillata 
(Hydrocharitaceae) in Northern California. Fla Entomol 77:221-230

Grodowitz MJ, Center TD, Snoddy E (1995) Current status of the use of insect biocontrol agents for the management of hydrilla. Miscellaneous paper A-95-3. US Army Engineer Research and Development Center, Vicksburg, pp 134-141

Grodowitz MJ, Center TD, Cofrancesco AF, Freedman JE (1997) Release and establishment of Hydrellia balciunasi (Diptera: Ephydridae) for the biological control of the submersed aquatic plant Hydrilla verticillata (Hydrocharitaceae) in the United States. Biol Control 9:15-23

Grodowitz MJ, Smart RM, Doyle RD, Owens CS, Bare R, Snell C, Freedman J, Jones H (2003) Hydrellia pakistanae and $H$. balciunasi insect biological agents of hydrilla: boon or bust? In: Cullen JM, Briese DT, Kriticos DJ, Lonsdale WM, Morin L, Scott, JK (eds) Proceedings of the XI international symposium on biological control of weeds. Canberra, Australia, pp 529-538

Grodowitz MJ, Nachtrieb J, Harms NE, Freedman J (2010) Suitability of using introduced Hydrellia spp. for management of monoecious Hydrilla verticillata (L.f) Royle. APCRP Technical Notes Collection, ERDC/TN APCRPBC-17. US Army Engineer Research and Development Center, Vicksburg

Hanlon SG, Hoyer MV, Cichra CE, Canfield DE Jr (2000) Evaluation of macrophyte control in 38 Florida lakes using triploid grass carp. J Aquat Plant Manag 38:48-54

Harms NE, Purcell M, Zhang J, Grodowitz MJ, Ding J (2017) Surveys for biological control agents of Hydrilla verticillata in the People's Republic of China in 2013 ERDC/EL TR-17-3. US Army Engineer Research and Development Center, Vicksburg

Madeira PT, Van TK, Steward KK, Schnell RJ (1997) Random amplified polymorphic DNA analysis of the phonetic relationships among world-wide accessions of Hydrilla verticillata. Aquat Bot 59:217-236

Madeira PT, Jacono CC, Van TK (2000) Monitoring hydrilla using two RAPD procedures and the nonindigenous database. J Aquat Plant Manag 38:33-40

Madeira PT, Van TK, Center TD (2004) An improved molecular tool for distinguishing monoecious and dioecious hydrilla. J Aquat Plant Manag 42:28-32

Madeira PT, Coetzee JA, Center TD, White EE, Tipping PW (2007) The origin of Hydrilla verticillata recently discovered at a South African dam. Aquat Bot 87:176-180

Michel A, Arias RS, Scheffler BE, Duke SO, Netherland MD, Dayan FE (2004) Somatic mutation-mediated evolution of herbicide resistance in the nonindigenous invasive plant hydrilla (Hydrilla verticillata). Mol Ecol 13:3229-3237

Owens CS, Grodowitz MJ, Smart RM, Harms NE, Nachtrieb JM (2006) Viability of hydrilla fragments exposed to different levels of insect herbivory. J Aquat Plant Manag 44:145-147
Owens CS, Grodowitz MJ, Smart RM (2008) Impact of insect herbivory on the establishment of Hydrilla verticillata (L.f.) Royle fragments. J Aquat Plant Manag 46:199-202

Reid CAM (1993) Donacia australasiae Blackburn: the sole representative of the subfamily Donaciinae (Coleoptera: Chrysomelidae) in Australia and New Guinea. J Aust Entomol Soc 32:103-111

Schmitz DC, Nelson BV, Nall LE, Schardt JD (1991) Exotic aquatic plants in Florida: a historical perspective and review of the present aquatic plant regulation program. In: Center TD, Doren RF, Hofstetter RL, Myers RL, Whiteaker LD (eds) Proceedings, symposium on exotic pest plants. National Park Service, United States Department of Interior, Washington, DC, pp 303-326

Steward KK, Van TK, Carter C, Pieterse AH (1984) Hydrilla invades Washington, DC, and the Potomac. Am J Bot 71:162-163

Stratman KN, Overholt WA, Cuda JP, Netherland MD, Wilson PC (2013a) Host range and searching behaviour of Cricotopus lebetis (Diptera: Chironomidae), a tip miner of Hydrilla verticillata (Hydrocharitaceae). Biocontrol Sci Technol 23:317-334

Stratman K, Overholt WA, Cuda JP, Netherland MD, Wilson PC (2013b) The diversity of Chironomidae (Diptera) associated with hydrilla in Florida. Fla Entomol 96:654-657

True-Meadows S, Haug EJ, Richardson RJ (2016) Monoecious hydrilla-a review of the literature. J Aquat Plant Manag 54:1-11

Wheeler GS, Center TD (2001) Impact of the biological control agent Hydrellia pakistanae (Diptera: Ephydridae) on the submersed aquatic weed Hydrilla verticillata (Hydrocharitaceae). Biol Control 21:168-181

Williams DA, Harms NE, Grodowitz MJ, Purcell M (2018) Genetic structure of Hydrilla verticillata L.f. Royle in eastern China and the Republic of Korea: implications for surveys of biological control agents for the invasive monoecious biotype. Aquat Bot 149:17-27

Yoshiyasu Y (1985) A systematic study of the Nymphulinae and the Musotiminae of Japan (Lepidoptera: Pyralidae). Sci Rep Kyoto Prefect Univ 37:1-162

Zhang J, Wheeler GS, Purcell MF, Ding J (2010) Biology, field host plants, and distribution of Macroplea japana in China; an unsuitable candidate for biological control of Hydrilla verticillata. Fla Entomol 93:116-119

Zhang J, Purcell M, Tian B, Ding J (2012) Progress report on field surveys to identify biocontrol agents of Hydrilla verticillata in China during 2011 ERDC/TN APCRP-BC22. US Army Engineer Research and Development Center, Vicksburg

Zhu J, Yu D, Xu X (2015) The phylogeographic structure of Hydrilla verticillata (Hydrocharitaceae) in China and its implications for the biogeographic history of this worldwide-distributed submerged macrophyte. Evol Biol 15:95 